\title{
Effects of Aliskiren, an RAAS inhibitor, on a carrageenan-induced pleurisy model of rats
}

\author{
YASIN BAYIR ${ }^{1}$, HARUN UN ${ }^{2}$, ELIF CADIRCI ${ }^{3}$, EROL AKPINAR $^{3}$, BUSRA \\ DIYARBAKIR ${ }^{3}$, ILKNUR CALIK ${ }^{4}$ and ZEKAI HALICI ${ }^{3}$
}

\author{
${ }^{1}$ Faculty of Pharmacy, Department of Biochemistry, Ataturk University Campus, 25240, Erzurum, Turkey \\ ${ }^{2}$ Faculty of Pharmacy, Department of Biochemistry, Agri Ibrahim Cecen University Campus 04100, Agri, Turkey \\ ${ }^{3}$ Faculty of Medicine, Department of Pharmacology, Ataturk University Campus 25240, Erzurum, Turkey \\ ${ }^{4}$ Department of Pathology, Erzurum Region Education and Research Hospital, Center 25100, Erzurum, Turkey
}

Manuscript received on February 6, 2018; accepted for publication on May 15, 2018

\begin{abstract}
How to cite: BAYIR Y, UN H, CADIRCI E, AKPINAR E, DIYARBAKIR B AND CALIK I. 2019. Effects of Aliskiren, an RAAS inhibitor, on a carrageenan-induced pleurisy model of rats. An Acad Bras Cienc 91: e20180106. DOI 10.1590/0001-3765201820180106.
\end{abstract}

\begin{abstract}
Our aim is to investigate the potentially preventive effects of Aliskiren in a carrageenaninduced lung pleurisy model and to compare the standard anti-inflammatory agents, indomethacin and dexamethasone. The pleurisy model was induced through the injection of carrageenan $(0.2 \mathrm{ml}-\% 2)$ into the pleural cavity. After the experiment, serum and lung tissues were collected and biochemical, molecular and pathological examinations were performed. In our study, pleural inflammation decreased superoxide dismutase activity and the glutathione level and increased the malondialdehyde level in the lung of rats, while Aliskiren increased the superoxide dismutase activity and glutathione level and decreased the malondialdehyde level. In addition, carrageenan-induced pleurisy caused a significant increase in proinflammatory cytokines mRNA expressions (TNF- $\alpha$, IL-1 $\beta$, and NF-KB), while Aliskiren administration decreased their expressions as well as the standard treatments, indomethacin and dexamethasone, did. Aliskiren administration at the $200 \mathrm{mg} / \mathrm{kg}$ dose protected the lungs in the pathological evaluation, especially against inflammatory cell infiltration and edematous lesions. It appears that Aliskiren protects the lung from carrageenan-induced pleurisy damage by regulating inflammation and antioxidant-oxidant balance via Renin Angiotensin Aldosterone System inhibition.
\end{abstract}

Key words: Aliskiren, cytokines, lung injury, oxidative stress, pleurisy, rat.

\section{INTRODUCTION}

Pleurisy is one the most prevalent inflammatory diseases and is characterized by an accumulation of an abnormal amount of pleural fluid in the pleural cavity (Hsieh et al. 2012). Various life-threatening diseases, such as tuberculosis, adenocarcinomas,

Correspondence to: Yasin Bayir

E-mail: yasinbayir@hotmail.com

ORCid: http://orcid.org/0000-0003-3562-6727 pneumonia, and myocardial infarction, are associated with pleurisy (Kass et al. 2007). Many studies have attempted to identify new markers to aid the diagnosis of pleurisy (Kass et al. 2007, Hsieh et al. 2012). Despite numerous studies aimed at identifying the mechanisms underlying the pathophysiology of pleurisy, there is no effective treatment protocol. Among pleural inflammation models, carrageenan (CAR)-induced pleurisy is a well-established model of acute inflammation, that 
permits the quantification and correlation of both exudate and cellular migration with changes in other inflammatory parameters (Moore 2003), and is frequently used to detect the anti-inflammatory effects of pharmaceutical agents (Cuzzocrea et al. 2004).

The renin-angiotensin-aldosterone system (RAAS) is a hormone system, which plays a role in the regulation of arterial blood pressure (Te Riet et al. 2015). When blood flow is reduced, renin is secreted from the kidney into the circulation. The plasma renin level is directly responsible for the level of angiotensin I (Ag I), into which angiotensinogen is converted (Te Riet et al. 2015). $\mathrm{Ag} \mathrm{I}$ is then converted into Ag II by the angiotensin converting enzyme (ACE) in the pulmonary surface and lung capillaries (Yee et al. 2010). Ag II plays major roles in the RAAS. These include arteriole constriction and multiple biological functions (Te Riet et al. 2015).

The expression of RAAS-related parameters in lung diseases, including a high level of ACE, activates the pulmonary RAAS (Hsieh et al. 2012, Yang et al. 2016). Previous studies examined the effects of the RAAS on pleurisy (Hsieh et al. 2012, Kim et al. 2016, Yang et al. 2016). Research showed that ACE levels played a pivotal role in the development of pleural effusions (Hsieh et al. 2012). RAAS blockers have anti-inflammatory effects and alleviate acute lung injury (Raiden et al. 2002).

Aliskiren (ALIS), an inhibitor of the renin, is currently used in antihypertensive treatment due to its effects on the rate-limiting step of the RAAS. A previous study reported that ALIS-induced inhibition of renin reduced organ failure in sepsisinduced lung injury (Akpinar et al. 2014). As RAAS blockers have anti-inflammatory effects and offer protection against pleurisy, the role of ALIS in pleurisy should be explored. However, no previous studies have investigated the effects of ALIS on CAR-induced pleurisy and lung injury.
We hypothesized that ALIS would inhibit the RAAS during pleurisy-induced lung injury and that it would concomitantly ameliorate inflammation and oxidative stress. Therefore, the aim of this study was to investigate the potential protective effects of ALIS in a model of CAR-induced lung injury and to compare its effects with that of standard antiinflammatory drug treatments (i.e., indomethacin [INDO] and dexamethasone [DEXA]).

\section{MATERIALS AND METHODS}

\section{ANIMALS}

The study consisted of 42 male, albino Wistar rats aged 11 weeks old, each weighing 200-220 g. The animals were obtained from Ataturk University's Experimental Animal Laboratory at the Medicinal and Experimental Application and Research Centre. The Institutional Animal Care and Use Ethics Committee of Ataturk University approved the study (Protocol number: 42190979-01-02/2232).

\section{EXPERIMENTAL DESIGN}

The rats were separated into the following seven groups, and each group consisted of six rats:

Group 1: Sham-operated control group (SHAM)

Group 2: CAR-only treated group (CAR)

Group 3: CAR plus $50 \mathrm{mg} / \mathrm{kg}$ of ALIS, administered orally (CAR+ALIS 50)

Group 4: CAR plus $100 \mathrm{mg} / \mathrm{kg}$ of ALIS, administered orally (CAR+ALIS 100)

Group 5: CAR plus $200 \mathrm{mg} / \mathrm{kg}$ of ALIS, administered orally (CAR+ALIS 200)

Group 6: CAR plus $5 \mathrm{mg} / \mathrm{kg}$ of INDO, administered orally (CAR+INDO)

Group 7: CAR plus $0.5 \mathrm{mg} / \mathrm{kg}$ of DEXA, administered intraperitoneally (CAR+DEXA)

PLEURISY MODEL

A CAR-induced pleurisy model was established, as previously described (Cuzzocrea et al. 1999). 
Anesthesia was induced through intraperitoneal administration of thiopental $(20 \mathrm{mg} / \mathrm{kg})$ and inhalation of $5 \%$ sevoflurane. ALIS (suspended in sterile saline) was given three times by oral gavage 3 days before the surgical procedure, and INDO (suspended in sterile saline) $(1 \mathrm{ml}, 5 \mathrm{mg} / \mathrm{kg}$, oral) and DEXA (dissolved in sterile saline) ( $2 \mathrm{ml}, 0.5$ $\mathrm{mg} / \mathrm{kg}$, intraperitoneal) were given $30 \mathrm{~min}$ before the surgical procedure.

After anesthesia, the rats were subjected to a skin incision at the right sixth intercostal space. The underlying muscle was dissected, and CAR $(0.2 \mathrm{ml}$, $2 \%$ prepared in sterile distilled water) was injected into the pleural cavity. The control group received vehicle administration for all procedures. The pleural incision was then closed using a $4 / 0$ sterile synthetic suture in two layers. For all experimental protocols all animals received metamizole sodium, an analgesic, intramuscular injection at the dose of $50 \mathrm{mg} / \mathrm{kg}$ after operation. Four hours after the CAR injection, the animals were killed with an overdose of a general anesthetic (thiopental sodium, 50 $\mathrm{mg} / \mathrm{kg}$ ), and blood samples were collected from their hearts. The serum samples were immediately separated by centrifugation at $4,000 \mathrm{rpm}$ for $10 \mathrm{~min}$ at $4^{\circ} \mathrm{C}$ and stored at $-80^{\circ} \mathrm{C}$ until they were assayed. The lung tissues were then quickly removed and washed in ice-cold saline. Half the tissues were transferred to a biochemistry laboratory and stored at $-80^{\circ} \mathrm{C}$ for biochemical and molecular analyses. The remaining tissues were fixed in a $10 \%$ formalin solution for histopathological analyses.

\section{BIOCHEMICAL INVESTIGATION OF LUNG TISSUE}

After the surgical procedures, the rat lung tissue was cleaned and fixed with liquid nitrogen and stored at $-80^{\circ} \mathrm{C}$. Subsequently, $100 \mathrm{mg}$ of all tissue samples were first perfused with $1 \mathrm{ml}$ PBS and then ground in liquid nitrogen using a Tissue Lyser II grinding jar set. After the grinding process, all samples were centrifuged. Superoxide dismutase activity (SOD)
(Sun et al. 1988), glutathione levels (GSH) (Sedlak and Lindsay 1968), and malondialdehyde levels (MDA) (Ohkawa et al. 1979) from each sample supernatant and standards were measured at room temperature in duplicate according to the modified methods with ELISA reader (Bayir et al. 2012). The results for the SOD, GSH, and MDA levels in the tissues were expressed as $\mathrm{U} / \mathrm{mg}$ protein, $\mathrm{nmol} /$ $\mathrm{mg}$ protein, and nmol/mg protein, respectively. All the data were presented as the mean \pm standard deviation results per $\mathrm{mg}$ of protein.

\section{PROTEIN DETERMINATION}

The protein concentrations were determined by the Lowry Method, using commercial protein standards (Sigma Aldrich, Total protein kit-TP0300-1KT(USA)).

\section{MOLECULAR INVESTIGATIONS}

\section{Total RNA Extraction and cDNA Synthesis}

Total RNA extraction and cDNA synthesis were performed according to our previous data (Albayrak et al. 2013). Tissues (20 mg) were briefly stabilized in an RNA stabilization reagent (RNAlater, Qiagen) and then disrupted using the TissueLyser II ( 2 x 2 minutes for lung tissues). Total RNA was purified using RNeasy Mini Kit Qiagen according to the instructions of the manufacturer in Qiaqube (Qiagen, Hilden, Germany). The RNA samples were reverse-transcribed into complementary DNA using a high-capacity cDNA reverse transcription kit (Applied Biosystem). From $10 \mu 1$, the total RNA was treated with $2 \mu 110 \mathrm{X}$ RT buffer, $0.8 \mu 125$ $\mathrm{X}$ dNTPs mix, $2 \mu \mathrm{l}$ 10X RT random primers, $1 \mu \mathrm{l}$ MultiScribe reverse transcriptase, and $4.2 \mu 1 \mathrm{DEPC}$ $\mathrm{H}_{2} \mathrm{O}$. Reverse transcription was carried out at $25^{\circ} \mathrm{C}$ for 10 minutes, then at $37^{\circ} \mathrm{C}$ for 120 minutes, and, finally, at $85^{\circ} \mathrm{C}$ for 5 minutes using a Veriti 96 Well Thermal Cycler (Applied Biosystem). The cDNA concentration and quality were assessed 
and quantified using the Epoch Spectrophotometer System and Take3 Plate (Biotek).

\section{RELATIVE QUANTIFICATION OF GENE EXPRESSION}

Relative TNF- $\alpha$, IL- $1 \beta$, and NF-KB expression analyses were performed with StepOne Plus Real Time PCR System technology (Applied Biosystem) using synthesized cDNA from rat lung RNA. A qPCR was run using TaqMan Probe mix, Taqman Probe-based technology (Applied Biosystem). A real-time PCR was performed using primers generated for rat TNF- $\alpha$ Rn00562055_m1, rat IL$1 \beta$ Rn00580432_m1, rat NF-KB Rn0399583_m1, and rat $\beta$-actin Rn00667869_m1. The results were expressed in relation to those associated with control animals. The expression data for $\beta$-actin in each tissue were used as endogenous controls. Primers and probes for $\beta$-actin were designed by Primer Design, Southampton, UK. For each tissue, triplicate determinations were performed in a 96well optical plate for both targets using $9 \mu 1$ of cDNA (100 ng), $1 \mu 1$ of Primer Perfect Probe mix, and $10 \mu 1$ of QuantiTect Probe PCR Master mix (Qiagen, Hilden, Germany) in each $20 \mu$ reaction. The plates were heated for 2 minutes at $50^{\circ} \mathrm{C}$ and for 10 minutes at $95{ }^{\circ} \mathrm{C}$. Subsequently, 40 cycles of 15 seconds at $94{ }^{\circ} \mathrm{C}$ and of 60 seconds at 60 ${ }^{\circ} \mathrm{C}$ were applied. All data were expressed as fold changes in expression compared to expression in other animal groups using the $2^{-\Delta \Delta \mathrm{Ct}}$ method (Livak and Schmittgen 2001).

\section{HISTOLOGICAL PROCEDURES}

Lung tissue samples were taken at necropsy and fixed in a $10 \%$ formaldehyde solution. Routine pathological processing was then performed, and the tissues were embedded in paraffin wax. From the paraffin wax block of each lung sample, 4-5 $\mu \mathrm{m}$ thick pieces were cut. After hematoxylin and eosin staining (H\&E), a pathologist examined the prepared slides using light microscopy using a digital camera (Olympus BX51, DP25 Olympus Optical, Tokyo, Japan). The following histopathological parameters were used for scoring: edema, emphysema, perivascular/peribronchiolar inflammation, thickness of the interalveolar septum, vascular congestion, and inflammatory cell infiltration. For each lung slide, a minimum of five fields was evaluated at $100 \times$ magnification, and the severity of changes was classified using a scoring system.

\section{STATISTICAL ANALYSIS}

For statistical analysis, SPSS, version 20.0 software was used. The results were presented as means \pm standard deviation (SD). Comparisons between groups were performed using a one-way analysis of variance and Duncan's multiple comparison tests. Statistical significance was accepted at $p<0.05$.

\section{RESULTS}

\section{BIOCHEMICAL RESULTS}

In this study, the activities of the SOD enzyme and levels of GSH and MDA were analyzed in a CAR-induced pleurisy model of rats (Fig. 1). SOD activity and GSH levels decreased significantly, whereas MDA levels increased significantly in the lungs of the CAR group as compared with those of the sham group, as shown in Figure $1(p<0.05)$. SOD activity and GSH levels were higher and MDA levels were lower in all the drug treatment groups as compared with those in the CAR group. As shown in Figure 1, at the SOD, GSH, and MDA amounts indicated, among the CAR+ALIS 50, CAR+ALIS 100, and CAR+ALIS 200 groups, the most effective dose of ALIS was $200 \mathrm{mg} / \mathrm{kg}$ ( $p<$ $0.05)$. Of the antioxidant and oxidant parameters measured, there was no significant difference between the CAR+ALIS 50 and CAR+ALIS 100 groups (Fig. 1). INDO and DEXA treatment decreased the MDA level and increased the SOD 


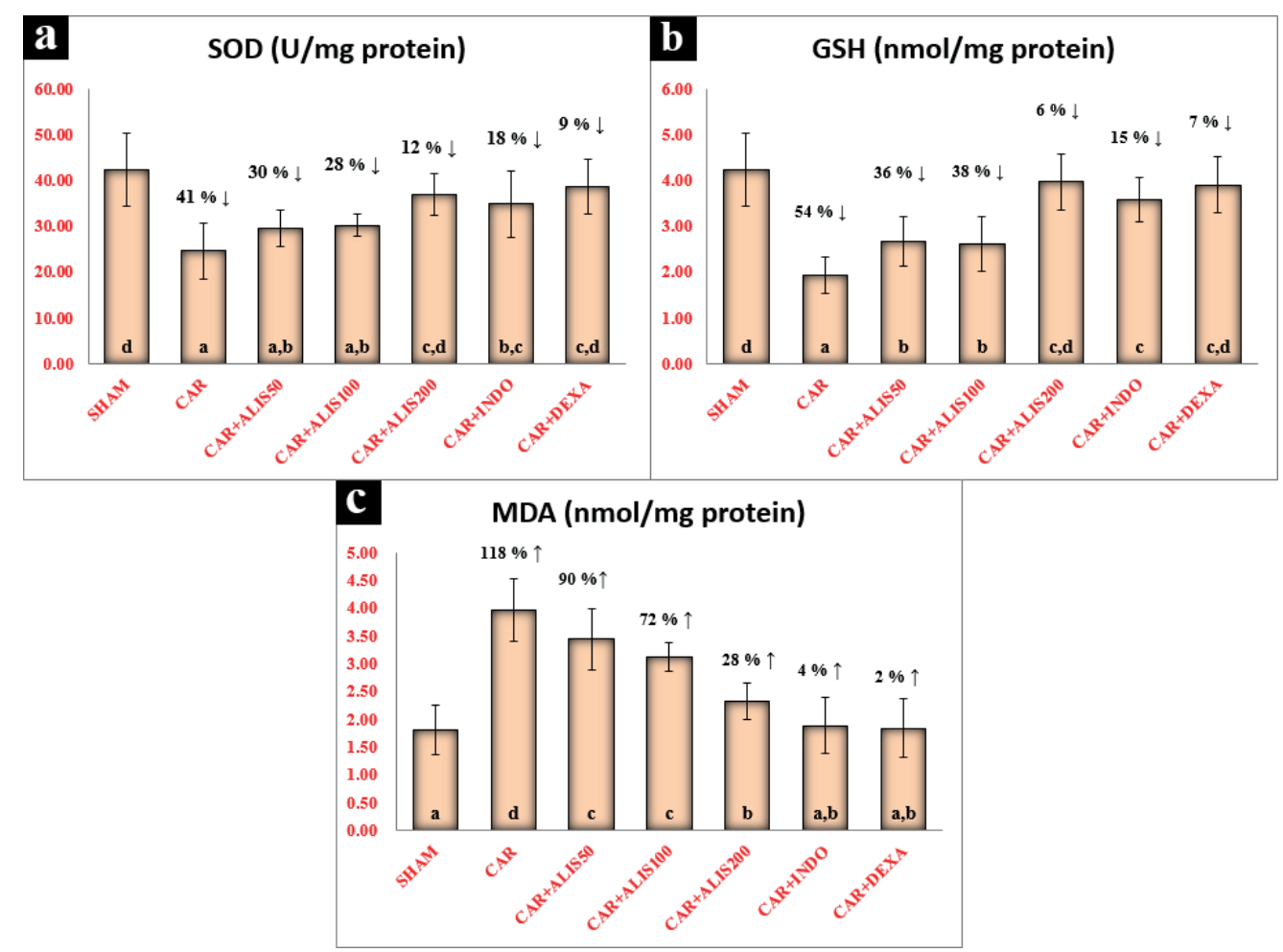

Figure 1 - Effects of Aliskiren treatments on SOD activity, GSH and MDA levels in rats' lungs. SHAM: Sham-operated, ALIS: Aliskiren 50-100-200 mg/kg, CAR: Carrageenan, INDO: Indomethacine, DEXA: Dexamethasone. Means in the same column by the same letter are not significantly different to the test of Duncan $(\mathrm{p}<0.05)$. Results are means \pm SD.

activity and GSH level as compared with the CAR group. However, it was not possible to completely recover these parameters as in the sham group ( $p$ $<0.05)$.

\section{MOLECULAR RESULTS}

The expression of TNF- $\alpha$, IL- $1 \beta$, and NF-KB mRNA in lung tissues is shown in Figure 2. In the CAR group, TNF- $\alpha$ (Fig. 2a) and IL-1 $\beta$ (Fig. 2b ) mRNA expression significantly increased as compared with that in the sham group $(p<0.05)$. All doses of ALIS decreased both TNF- $\alpha$ and IL$1 \beta$ mRNA expression as compared with that in the CAR group. The CAR+INDO, CAR+DEXA, and CAR+ALIS 200 treatments induced antiinflammatory effects and significantly decreased TNF- $\alpha$ and IL- $1 \beta$ mRNA expression as compared with that in the CAR group $(p<0.05)$.
In the CAR-only group, NF-KB, expression increased significantly as compared with that in the sham group (Fig. 2c) $(p<0.05)$. While there was no significant difference between the CAR, CAR+ALIS50, and CAR+ALIS100 groups, ALIS200 treatments significantly decreased NF$\mathrm{KB}$ expression compared to the CAR group ( $p<$ $0.05)$. In the NF-KB mRNA expressions, the most significant effects were shown in the CAR+INDO and CAR+DEXA groups compared to the CAR group $(p<0.05)$.

\section{HISTOPATHOLOGICAL RESULTS}

Lung tissues in the sham group showed a normal histological structure (Fig. 3a). The results of the histopathological assessment of the lungs in the different groups are presented in Table I. The CAR group showed severe emphysema, perivascular/ 


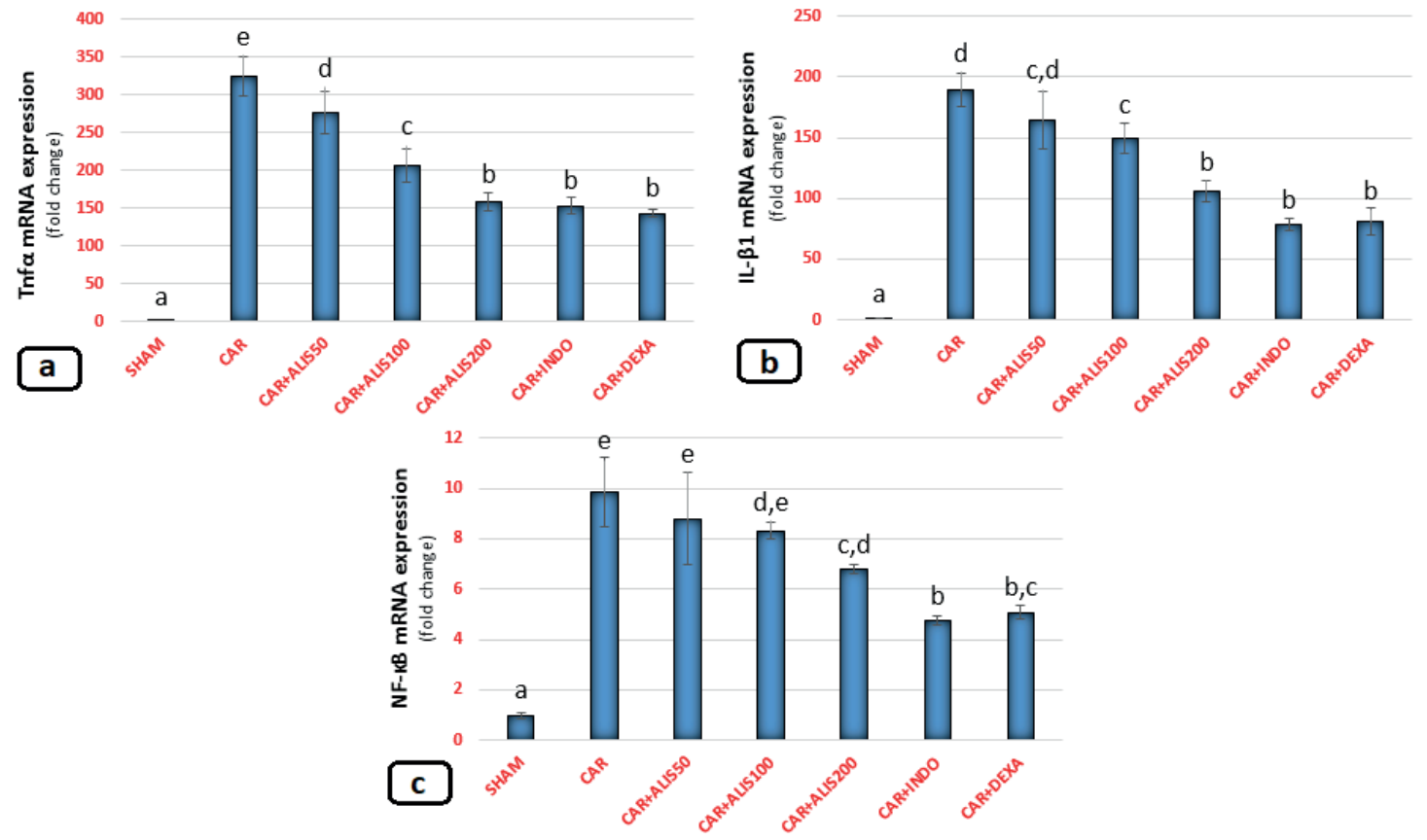

Figure 2 - Effects of Aliskiren treatments on relative mRNA expression levels of TNF- $\alpha$, IL-1 $\beta$, and NF-KB in rats' lungs. Expressions of mRNAs were detected by quantitative real time PCR analysis. $\beta$-actin was used as the reference gene. Results are expressed as relative-fold compared to sham animals. Gene-specific probes were used as outlined under Material and Methods. The relative expression levels were calculated by the $\Delta \Delta C T$ method. SHAM: Shamoperated, ALIS: Aliskiren 50-100-200 mg/kg, CAR: Carrageenan, INDO: Indomethacine, DEXA: Dexamethasone. Means in the same column by the same letter are not significantly different to the test of Duncan $(\mathrm{p}<0.05)$. Results are means $\pm \mathrm{SD}$.

peribronchiolar inflammation, thickness in the interalveolar septum, inflammatory cell infiltration, moderate edema, and vascular congestion (Fig. $3 b)$. The CAR+DEXA group had fewer lesions (Fig. 3c) than the CAR group. The CAR+INDO group showed a low to moderate number of lesions (Fig. 3d). In the treatment groups, the CAR+ALIS 200 group had fewer lesions (mild to moderate) (Fig. 3g) than the CAR+ALIS 50 (Fig. 3e) and CAR+ALIS 100 groups (Fig. 3f).

\section{DISCUSSION}

The present study revealed protective effects of ALIS in a CAR-induced pleurisy rat model. ALIS significantly alleviated lung injury of rats after CAR-induced pleurisy, and its effects were comparable to those of INDO and DEXA, standard anti-inflammatory agents. The findings suggest that ALIS could be used to prevent lung injury by decreasing tissue damage, overexpression of tissue proinflammatory cytokines, and oxidative stress caused by pleurisy. Furthermore, they indicate that the protective effects of ALIS could result in RAAS blockage.

Previous studies of the association of the RAAS with the inflammatory process showed that modulating RAAS via renin inhibition prevented various conditions, such as ischemiareperfusion and sepsis, associated with metabolic disorders (Akpinar et al. 2014, Un et al. 2015, Karcioglu et al. 2016). However, neither the role of renin inhibition in acute inflammation nor the role of inflammatory cytokines in inflammationinduced lung injury has been studied. During the inflammatory process, vascular permeability and leucocyte migration increase, followed by changes 


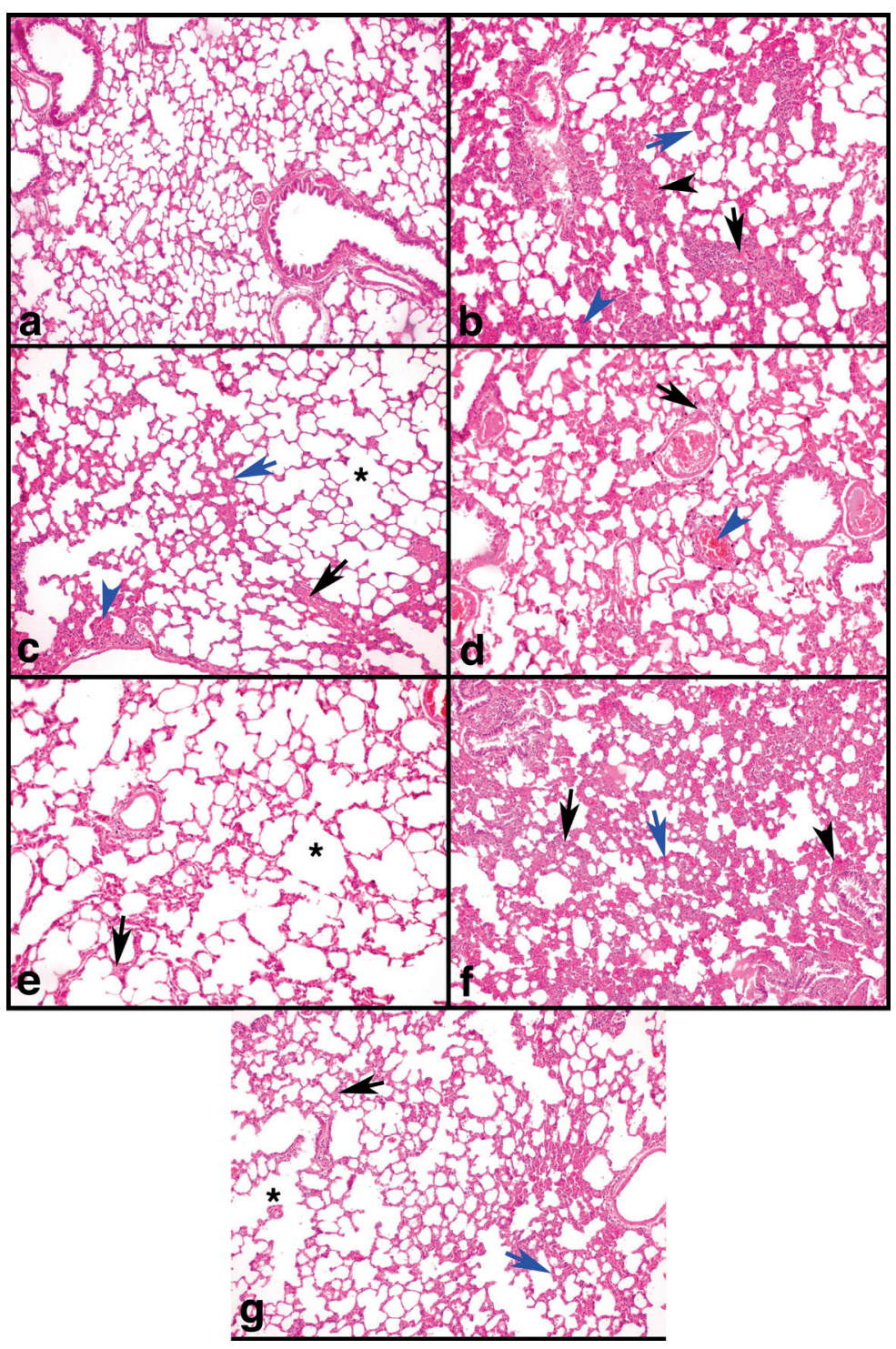

Figure 3 - a-g: Effects of Aliskiren treatments on light micrographs in rats' lung tissues. a) SHAM group animal lung section showed normal histologic features. Haematoxylin and eosin staining. Magnification, 100X. b) CAR group animal lung section has severe edema (black arrow), Perivascular /Peribronchiolar inflammation (black arrow head), thickness in interalveolar septum and inflammatory cell infiltration (blue arrow) and vascular congestion (blue arrow head). Haematoxylin and eosin staining. Magnification, 100X. c) CAR+DEXA group animal lung section showed mild emphysema (asterisk), moderate edema (black arrow), mild thickness in interalveolar septum and inflammatory cell infiltration (blue arrow) and mild vascular congestion (blue arrow head). Haematoxylin and eosin staining. Magnification, 100X. d) CAR+INDO group animal lung section showed moderate edema (black arrow), mild thickness in interalveolar septum and inflammatory cell infiltration (blue arrow) and mild vascular congestion (blue arrow head). Haematoxylin and eosin staining. Magnification, 100X. e) CAR+ALIS50 group animal lung section showed moderate edema (arrow), emphysema (asterisk), perivascular /peribronchiolar inflammation, thickness in interalveolar septum, vascular congestion, inflammatory cell infiltration. Haematoxylin and eosin staining. Magnification, 100X. f) CAR+ALIS100 group animal lung section showed moderate edema (black arrow), mild emphysema, severe perivascular /peribronchiolar inflammation (black arrow head) and thickness in interalveolar septum and inflammatory cell infiltration (blue arrow), vascular congestion. Haematoxylin and eosin staining. Magnification, 100X. g) CAR+ALIS200 group animal lung section showed mild edema (black arrow), moderate emphysema (asterisk), mild perivascular /peribronchiolar inflammation, thickness in interalveolar septum and inflammatory cell infiltration (blue arrow). Haematoxylin and eosin staining. Magnification, 100X. SHAM: Sham-operated, ALIS: Aliskiren 50-100-200 mg/kg, CAR: Carrageenan, INDO: Indomethacine, DEXA: Dexamethasone. 
TABLE I

Histopathological assessments of lungs.

\begin{tabular}{|c|c|c|c|c|c|c|c|}
\hline & SHAM & CAR & $\begin{array}{l}\text { CAR+ } \\
\text { DEXA }\end{array}$ & $\begin{array}{l}\text { CAR+ } \\
\text { INDO }\end{array}$ & $\begin{array}{c}\text { CAR+ } \\
\text { ALIS50 }\end{array}$ & $\begin{array}{c}\text { CAR+ } \\
\text { ALIS100 }\end{array}$ & $\begin{array}{c}\text { CAR+ } \\
\text { ALIS200 }\end{array}$ \\
\hline Edema & 0 & +2 & +2 & +2 & +2 & +2 & +1 \\
\hline Emphysema & 0 & +3 & +1 & +1 & +2 & +1 & +2 \\
\hline $\begin{array}{l}\text { Perivascular / } \\
\text { Peribronchiolar } \\
\text { inflammation }\end{array}$ & 0 & +3 & +1 & +1 & +2 & +3 & +1 \\
\hline $\begin{array}{l}\text { Thickness in interalveolar } \\
\text { septum }\end{array}$ & 0 & +4 & +1 & +1 & +2 & +2 & +1 \\
\hline Vascular congestion & 0 & +2 & +1 & +1 & +2 & +2 & +1 \\
\hline $\begin{array}{l}\text { Inflammatory cell } \\
\text { infiltration }\end{array}$ & 0 & +3 & $+1 /+2$ & +1 & +2 & +2 & +2 \\
\hline
\end{tabular}

in levels of proinflammatory cytokines (e.g., TNF- $\alpha$ and IL-1 $\beta$ ), free radicals (e.g., superoxide), and inflammatory mediators (e.g., neutrophilmediated reactive oxygen species) (Cadirci et al. 2016). Tissue activation by phagocytic cells results in the uncontrolled release of pathophysiologically proinflammatory cytokines, such as TNF- $\alpha$ (Zanotti et al. 2002, Cadirci et al. 2013). Previous research demonstrated that the aforementioned process aggravated inflammation and multisystem organ failure in an experimentally induced inflammation model (Cadirci et al. 2016). Studies also showed that Ag II, the most important effector of the RAAS, contributed to tissue repair and leucocyte accumulation from the blood circulation in interstitial tissues during the inflammation process (Touyz 2005). In a clinical study, researchers demonstrated increased levels of ACE, which converts Ag I into Ag II, in pleural effusions (Hsieh et al. 2012). Another study showed that increased Ag II levels were directly related to pleural inflammation and that losartan, an Ag II type-1 (AT1) receptor blocker, reduced the adverse effects of Ag II in pleural mesothelial cell culture (Yang et al. 2016). The same study showed that Ag II induced the activation of the NF-KB signaling pathway through pleural inflammation and that losartan decreased NF-KB mRNA expression in pleural cells. In parallel with these results, the current study showed that the ALIS treatments decreased NF-KB levels in lung tissue in a CARinduced pleurisy model. When the rats were treated with low- and middle-level doses of ALIS (50 and $100 \mathrm{mg} / \mathrm{kg}$ ), there was no significant decrease in NF-KB mRNA expression in lung tissues. In contrast, the administration of $200 \mathrm{mg} / \mathrm{kg}$ of ALIS to rats with CAR-induced pleurisy decreased NF$\mathrm{KB}$ expression in tissues to those of sham levels. These findings suggest that a high dose of ALIS can prevent CAR-induced lung injury.

The activation of NF-KB involves a major signal transduction pathway, which regulates the expression of genes related to inflammation. NF$\mathrm{KB}$ regulates the expression of many cytokines, such as TNF- $\alpha$ and IL-1 $\beta$, related to inflammatory responses, with TNF- $\alpha$ playing a major role (Schreiber et al. 1999, He et al. 2007). A previous study showed that losartan decreased TNF- $\alpha$ and IL-1 $\beta$ levels (Imai et al. 2005, Yuksel et al. 2015). Research also demonstrated that ALIS treatment reduced levels of TNF- $\alpha$ and IL- $1 \beta$ in acute lung injury (Akpinar et al. 2014). In accordance with these results, we showed that ALIS treatment decreased TNF- $\alpha$ and IL- $1 \beta$ mRNA expression in CAR-induced lung injury, with the strongest effect apparent in the $200 \mathrm{mg} / \mathrm{kg}$ treatment group. 
The results of the present study also showed that the RAAS had an important impact on pleural inflammation and inflammatory mediators, in contrast to the findings of two studies in the literature (Raghavendra and Kulkarni 2000, Carvalho et al. 2006). In the first study, losartan treatment increased inflammation (edema volume). Researchers showed that TNF- $\alpha$ and IL- $1 \beta$ levels increased in the CAR-induced paw edema model, but they could not show the protective effect of losartan on TNF- $\alpha$ and IL- $1 \beta$ levels (Carvalho et al. 2006). In the second study, the researchers showed that losartan potentiated acute inflammation (Raghavendra and Kulkarni 2000). They attributed this potentiation to the stimulation of inflammatory pathways by unknown mechanisms. As demonstrated in the aforementioned studies, the inflammatory process includes many complex pathways and mechanisms, some of which remain unknown. Thus, the present study examined the potential involvement of TNF- $\alpha$, IL- $1 \beta$, and NF$\mathrm{KB}$ in mechanisms underlying the inflammatory process.

Free oxygen radicals play important roles in the inflammation mechanism and tissue injury (Fink 2002, Un et al. 2015). Previous research showed that free radicals, such as oxygen radicals, hydrogen peroxide, and hydroxyl anions, increased during the inflammatory process (Tanas et al. 2010). Antioxidant molecules and drug treatments showed protective effects through the elimination of these free radicals (Halici et al. 2007, Karakus et al. 2013). Antioxidant defense systems include many enzymes, such as SOD and GSH, which limit the cytotoxic effects of free oxygen radicals (Fink 2002). Many previous studies demonstrated that levels of antioxidants decreased in CARinduced pleurisy (Nardi et al. 2007, Cai et al. 2014). A number of studies also demonstrated a relationship between the RAAS and oxidative stress (Ziypak et al. 2015, Bayir et al. 2016, Halici et al. 2016). For example, Akpinar et al. showed that an excessively high level of Ag II due to RAAS activation increased the level of MDA, which is the end product of oxidative damage of cell membrane phospholipids, and decreased SOD activity and GSH levels (Akpinar et al. 2014). In line with these results, in the present study, a high dose of ALIS $(200 \mathrm{mg} / \mathrm{kg})$ significantly decreased SOD activity and GSH levels in the CAR-induced inflammation group as compared with that in the sham group. In addition, MDA levels increased significantly in the high-dose ALIS treatment group. No significant differences in SOD activity, GSH level or MDA levels were apparent between the ALIS 200 group and INDO and DEXA groups. These results suggest that renin inhibition by ALIS provided protection against oxidative stress damage.

In the present study, the histopathological analysis of lung tissues revealed increased inflammatory cell infiltration, edema, vascular congestion, and vascular and interalveolar inflammation following CAR administration. In contrast, ALIS treatment decreased these effects, with the optimum protective effects observed at an ALIS dose of $200 \mathrm{mg} / \mathrm{kg}$. treatment. In the current study, both the histopathological findings and cytokine mRNA levels pointed to protective effects of ALIS on lungs during inflammation.

Many studies in the literature support the finding of the present study that RAAS inhibition plays a protective role against tissue damage (Halici et al. 2009, Sipal et al. 2012), especially via renin inhibition (Akpinar et al. 2014, Un et al. 2015). The present study indicated that renin inhibition was involved in the pathogenesis of the acute inflammatory response in a CAR-induced rat model of pleurisy. The inflammatory markers detected through molecular, biochemical, and histopathological assessments of lung tissue in the present study support this idea. Moreover, this study showed that DEXA, INDO, and ALIS provided protection against the increase in inflammatory cytokines induced by CAR. These data suggest that 
RAAS inhibition in the first step in the suppression of inflammation, oxidative stress, and tissue injury in CAR-induced pleurisy in a rat model.

\section{ACKNOWLEDGMENTS}

This research supported by funding of Ataturk University (BAP-2014/170) scientific research project. The authors thank the Ataturk University for the opportunity to undertake this study, and allowing the use of the facilities within the university. Also all authors thank to School of Medicine, Molecular Pharmacology Laboratory team for their hard work on the development, data analysis and preparation of this article.

\section{REFERENCES}

AKPINAR E, HALICI Z, CADIRCI E, BAYIR Y, KARAKUS E, CALIK M, TOPCU A AND POLAT B. 2014. What is the role of renin inhibition during rat septic conditions: preventive effect of aliskiren on sepsis-induced lung injury. Naunyn Schmiedebergs Arch Pharmacol 387: 969-978.

ALBAYRAK A, HALICI Z, CADIRCI E, POLAT B, KARAKUS E, BAYIR Y, UNAL D, ATASOY M AND DOGRUL A. 2013. Inflammation and peripheral 5-HT7 receptors: the role of 5-HT7 receptors in carrageenan induced inflammation in rats. Eur J Pharmacol 715: 270279.

BAYIR Y ET AL. 2016. Aliskiren - a promising strategy for ovarian ischemia/reperfusion injury protection in rats via RAAS. Gynecol Endocrinol 32: 675-683.

BAYIR Y, KARAGOZ Y, KARAKUS E, ALBAYRAK A, SENGUL O, CAN I, YAYLA N, KUSKUN U AND KELES MS. 2012. Nigella sativa reduces tissue damage in rat ovaries subjected to torsion and detorsion: oxidative stress, proinflammatory response and histopathological evaluation. Gynecol Obstet Invest 74: 41-49.

CADIRCI E ET AL. 2013. Peripheral 5-HT7 receptors as a new target for prevention of lung injury and mortality in septic rats. Immunobiology 218: 1271-1283.

CADIRCI E, HALICI Z, YAYLA M, TOKTAY E, BAYIR Y, KARAKUS E, TOPCU A, BUYUK B AND ALBAYRAK A. 2016. Blocking of urotensin receptors as new target for treatment of carrageenan induced inflammation in rats. Peptides 82: 35-43

CAI C, CHEN Y, ZHONG S, JI B, WANG J, BAI X AND SHI G. 2014. Anti-inflammatory activity of N-butanol extract from Ipomoea stolonifera in vivo and in vitro. PLoS One 9: e95931.
CARVALHO RF, RIBEIRO RA, FALCAO RA, LIMA RC, LEITAO RF, ALCANTARA C, SOUZA MH, CUNHA FQ AND BRITO GA. 2006. Angiotensin II potentiates inflammatory edema in rats: Role of mast cell degranulation. Eur J Pharmacol 540: 175-182.

CUZZOCREA S ET AL. 1999. Role of IL-6 in the pleurisy and lung injury caused by carrageenan. J Immunol 163: 5094-5104.

CUZZOCREA S ET AL. 2004. Rosiglitazone, a ligand of the peroxisome proliferator-activated receptor-gamma, reduces acute inflammation. Eur J Pharmacol 483: 79-93.

FINK MP. 2002. Reactive oxygen species as mediators of organ dysfunction caused by sepsis, acute respiratory distress syndrome, or hemorrhagic shock: potential benefits of resuscitation with Ringer's ethyl pyruvate solution. Curr Opin Clin Nutr Metab Care 5: 167-174.

HALICI Z, BILEN H, ALBAYRAK F, UYANIK A, CETINKAYA R, SULEYMAN H, KELES ON AND UNAL B. 2009. Does telmisartan prevent hepatic fibrosis in rats with alloxan-induced diabetes? Eur J Pharmacol 614: 146-152.

HALICI Z, DENGIZ GO, ODABASOGLU F, SULEYMAN H, CADIRCI E AND HALICI M. 2007. Amiodarone has anti-inflammatory and anti-oxidative properties: an experimental study in rats with carrageenan-induced paw edema. Eur J Pharmacol 566: 215-221.

HALICI Z, POLAT B, CADIRCI E, TOPCU A, KARAKUS E, KOSE D, ALBAYRAK A AND BAYIR Y. 2016. Inhibiting renin angiotensin system in rate limiting step by aliskiren as a new approach for preventing indomethacin induced gastric ulcers. Chem Biol Interact 258: 266-275.

HE X, HAN B, MURA M, XIA S, WANG S, MA T, LIU M AND LIU Z. 2007. Angiotensin-converting enzyme inhibitor captopril prevents oleic acid-induced severe acute lung injury in rats. Shock 28: 106-111.

HSIEH WY ET AL. 2012. ACE/ACE2 ratio and MMP-9 activity as potential biomarkers in tuberculous pleural effusions. Int J Biol Sci 8: 1197-1205.

IMAI Y ET AL. 2005. Angiotensin-converting enzyme 2 protects from severe acute lung failure. Nature 436: 112116.

KARAKUS E, HALICI Z, ALBAYRAK A, BAYIR Y, AYDIN A, UNAL D, CADIRCI E, FERAH I AND ODACI E. 2013. Beneficial pharmacological effects of levosimendan on antioxidant status of acute inflammation induced in paw of rat: involvement in inflammatory mediators. Basic Clin Pharmacol Toxicol 112: 156-163.

KARCIOGLU SS, PALABIYIK SS, BAYIR Y, KARAKUS E, MERCANTEPE T, HALICI Z AND ALBAYRAK A. 2016. The Role of RAAS Inhibition by Aliskiren on Paracetamol-Induced Hepatotoxicity Model in Rats. J Cell Biochem 117: 638-646. 
KASS SM, WILLIAMS PM AND REAMY BV. 2007. Pleurisy. Am Fam Physician 75: 1357-1364.

KIM J, LEE JK, HEO EY, CHUNG HS AND KIM DK. 2016. The association of renin-angiotensin system blockades and pneumonia requiring admission in patients with COPD. Int J Chron Obstruct Pulmon Dis 11: 2159-2166.

LIVAK KJ AND SCHMITTGEN TD. 2001. Analysis of relative gene expression data using real-time quantitative PCR and the 2(T)(-Delta Delta C) method. Methods 25: 402-408.

MOORE AR. 2003. Pleural models of inflammation: immune and nonimmune. Methods Mol Biol 225: 123-128.

NARDI GM, SIQUEIRA JUNIOR JM, DELLE MONACHE F, PIZZOLATTI MG, CKLESS K AND RIBEIRO-DOVALLE RM. 2007. Antioxidant and anti-inflammatory effects of products from Croton celtidifolius Bailon on carrageenan-induced pleurisy in rats. Phytomedicine 14: 115-122.

OHKAWA H, OHISHI N AND YAGI K. 1979. Assay for lipid peroxides in animal tissues by thiobarbituric acid reaction. Anal Biochem 95: 351-358.

RAGHAVENDRA V AND KULKARNI SK. 2000. AT1 receptor antagonism enhances angiotensin-II-facilitated carrageenan-induced paw edema. Methods Find Exp Clin Pharmacol 22: 633-636.

RAIDEN S, NAHMOD K, NAHMOD V, SEMENIUK G, PEREIRA Y, ALVAREZ C, GIORDANO M AND GEFFNER JR. 2002. Nonpeptide antagonists of AT1 receptor for angiotensin II delay the onset of acute respiratory distress syndrome. J Pharmacol Exp Ther 303: 45-51.

SCHREIBER S, NIKOLAUS S, HAMPE J, HAMLING J, KOOP I, GROESSNER B, LOCHS H AND RAEDLER A. 1999. Tumour necrosis factor alpha and interleukin lbeta in relapse of Crohn's disease. Lancet 353: 459-461.

SEDLAK J AND LINDSAY RH. 1968. Estimation of total, protein-bound, and nonprotein sulfhydryl groups in tissue with Ellman's reagent. Anal Biochem 25: 192-205.

SIPAL S ET AL. 2012. Comparative study of three angiotensin II type 1 receptor antagonists in preventing liver fibrosis in diabetic rats: stereology, histopathology, and electron microscopy. J Mol Histol 43: 723-735.

SUN Y, OBERLEY LW AND LI Y. 1988. A simple method for clinical assay of superoxide dismutase. Clin Chem 34: 497-500.

TANAS S, ODABASOGLU F, HALICI Z, CAKIR A, AYGUN H, ASLAN A AND SULEYMAN H. 2010. Evaluation of anti-inflammatory and antioxidant activities of Peltigera rufescens lichen species in acute and chronic inflammation models. J Nat Med 64: 42-49.

TE RIET L, VAN ESCH JH, ROKS AJ, VAN DEN MEIRACKER AH AND DANSER AH. 2015. Hypertension: renin-angiotensin-aldosterone system alterations. Circ Res 116: 960-975.

TOUYZ RM. 2005. Molecular and cellular mechanisms in vascular injury in hypertension: role of angiotensin II. Curr Opin Nephrol Hypertens 14: 125-131.

UN H, BAYIR Y, HALICI Z, AKPINAR E, KARAKUS E, ORAL A, ZIYPAK T AND SELLI J. 2015. The Effects of RAAS Inhibition in Rate Limiting Step by Aliskiren on Testicular Torsion Injury in Rats. J Urol 194: 828-833.

YANG J ET AL. 2016. Activation of calpain by reninangiotensin system in pleural mesothelial cells mediates tuberculous pleural fibrosis. Am J Physiol Lung Cell Mol Physiol 311: L145-153.

YEE AH, BURNS JD AND WIJDICKS EF. 2010. Cerebral salt wasting: pathophysiology, diagnosis, and treatment. Neurosurg Clin N Am 21: 339-352.

YUKSEL TN, HALICI Z, DEMIR R, CAKIR M, CALIKOGLU C, OZDEMIR G AND UNAL D. 2015. Investigation of the effect of telmisartan on experimentally induced peripheral nerve injury in rats. Int J Neurosci 125: 464-473.

ZANOTTI S, KUMAR A AND KUMAR A. 2002. Cytokine modulation in sepsis and septic shock. Expert Opin Investig Drugs 11: 1061-1075.

ZIYPAK T ET AL. 2015. Renoprotective effect of aliskiren on renal ischemia/reperfusion injury in rats: electron microscopy and molecular study. Ren Fail 37: 343-354. 